\title{
Telehealth Business Potential in Indonesia
}

\author{
Novita Rina Antarsih ${ }^{1, *}$ Sri Panca Setyawati ${ }^{2}$,Sri Ningsih ${ }^{3,}$ Deprizon ${ }^{4}$ Eman \\ Sulaiman $^{5}$ Nurul Pujiastuti ${ }^{6}$ \\ ${ }^{I}$ Department Midwifery of Health Polytechnic of Ministry of Health Jakarta III, Bekasi, Indonesia \\ ${ }^{2}$ Faculty of Teacher Training and Education of Nusantara PGRI University, Kediri, Indonesia \\ ${ }^{3}$ Department of Midwifery of Akademi Kebidanan Tahirah Al Baeti, Bulukumba, Indonesia \\ ${ }^{4}$ Faculty of Islamic Studies Muhammadiyah Riau University, Pekanbaru, Indonesia \\ ${ }^{5}$ Department Management of Sekolah Tinggi Ilmu Ekonomi Cirebon, Cirebon, Indonesia \\ ${ }^{6}$ Department Nursing of Health Polytechnic of Ministry of Health Malang, Malang, Indonesia \\ ${ }^{*}$ Corresponding author. Email: novitanuradi@gmail.com
}

\begin{abstract}
The purpose of this study is to describe possible Telehealth business opportunities in Indonesia using a narrative approach. This literature review uses articles related to telehealth. This database uses secondary data in the infographic-Katadata. The biggest challenge in Indonesia is the ratio of doctors to the Indonesian population under WHO standards and health protocol policies during the COVID-19 pandemic, causing telehealth to develop rapidly. The findings show some opportunities of telehealth business development namely; demographic bonus (298 million from 2020-2024), high cases of non-communicable diseases (71\%), the increasing of JKN participants (222.4 million), low number of health workers ( 0.4 doctors per 1,000 population), high level of satisfaction in hospital telemedicine $(71 \%)$, telehealth users (32 million), large online service provider TEMENIN from the Ministry of Health with 11 platforms. There is a cooperation scheme from various ministries, as well as support from the government in regulations. It can be concluded that the development of telehealth business in Indonesia is very profitable.
\end{abstract}

Keywords: Telehealth, business, Covid-19

\section{INTRODUCTION}

The Covid 19 pandemic has altered our live in many sectors and force us to apply social distancing in daily live. Following directions from the Centers for Disease Control, and Prevention (CDC) to people and health care providers in areas of the Coronavirus (COVID-19) pandemic to implement social distancing practices, specifically recommend that healthcare facilities and providers use virtualized on clinical services.[1] Telemedicine is an interactive communication service between patients and doctors in distant places to improve patient health. Calton, et.al (2020) said that telemedicine has been done in the U.S before the arrival of Covid-19.[2] Patients who receive palliative care by telemedicine are typically very satisfied because they save more time. Telehealth refers to telecommunications and information technology (IT) to access health assessment, diagnosis, intervention, consultation, surveillance, and information across distances.
It suggests that telehealth is a broader concept of telemedicine. Telemedicine has been used since ancient hieroglyphs and scrolls to share information about epidemic conditions. Its use is increasing in the current outbreak conditions, namely the coronavirus disease 2019 (COVID-19).[3] This outbreak resulted in many businesses closing. The healthcare industry has also been badly affected by the COVID-19 pandemic.[4] It is the low number of patient visits that have an impact on decreasing income. The solution is telehealth instead of direct patient visits.[5] Indonesia has a big challenge because it only has 4 doctors serving its 10,000 population.[6] Therefore, the Telehealth program is very potential and need to be implemented because ideally suit to meet the demands of large amount Indonesian people in healthcare delivery system especially during the Covid-19 pandemic. It overcomes physical barriers in providing patients and caregivers access into convenient medical care. 


\section{LITERATURE REVIEW}

Business potential owned by Indonesia is the population. Indonesia's large population (demographic bonus) can be the key to success in increasing Indonesia's competitiveness. During the COVID-19 pandemic and the WHO has designated it as a Pandemic [7]. Almost all economic sectors experienced sluggishness, and few were able to survive. [8]. The health sector showed a sharp increase. An example of a hand sanitizer product is a product to prevent the spread of the virus with the highest purchasing power is $5585 \%$, followed by an increase in interest spending up to $1986 \%$. For ordinary thermometers, there is an increase of up to $1007 \%$. While the mouth mask is an increase in buying interest up to $167 \%$ [9].

Telehealth is an alternative product or medical device that is very suitable for Indonesia's demographic conditions during a pandemic with limited access to health facilities, social and economic centers so that patients need information regularly about health, consultation, and treatment are hampered, thus requiring information technology of health [10]. Healthcare systems with telehealth sustain the continuity of outpatient patient care during this pandemic-in the midst of "stay-at-home" orders and physical distancing measures, while reducing community and nosocomial spread [11]

\section{METHOD}

This study is conducted based on narrative approach to describe potential opportunities of telehealth busines in Indonesia. The information are gathered from some published articles related with telehealth and combined with data from infographic -Katadata as secondary data. In order to achieve a narrative review article, the information are summarized based on situational analysis.

\section{RESULT AND DISCUSSION}

E-health (telehealth) is an information and communication technology for health services, primarily to improve the quality of health care services and work processes during Covid-19 pandemic for more effective and efficient. In general, e-health consists of health informatics and remote health efforts (telehealth). [12]

Indonesia is a developing country with large population. The implementation of telehealth by integrating within the national health system is urgently done to fight the Covid 19 pandemic. In this context, some challenges will be faced and need creative strategy. All stakeholders must be encouraged to address the challenges and collaborate to promote the safe and evidence-based use of telehealth during the current pandemic and future outbreaks. However, Indonesia still has many possibilities and opportunities to develop telehealth due to this program is very profitable. Situation Analysis in Indonesia:

\subsection{Demographic Bonus}

The demographic bonus is the impact of changes in the age structure of the population on the economy. This economic advantage is an increase in per capita income or asset accumulation due to a decrease in the number of people borne by the working-age population base on the Dependency Ratio (RK). A country will benefit when RK decreases. [13]

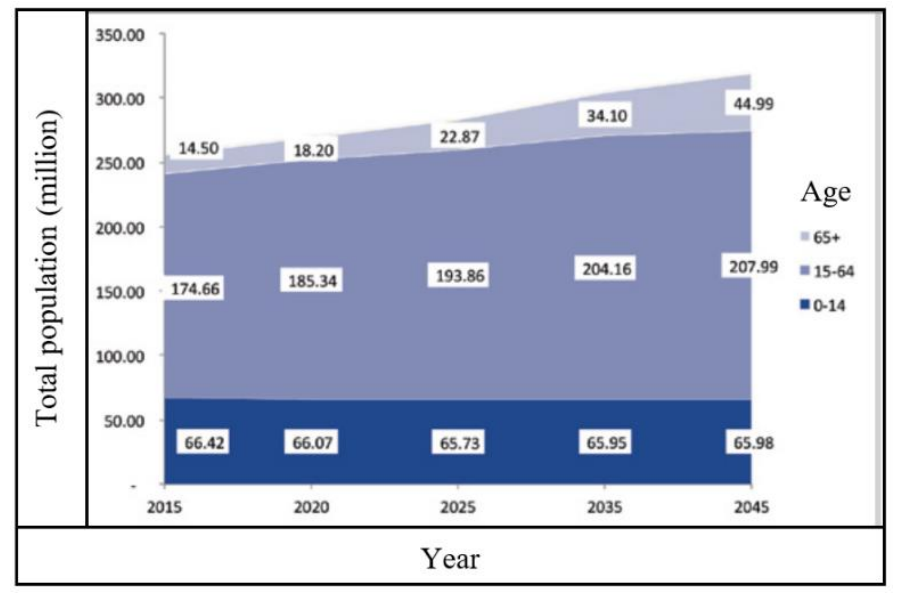

Figure 1 Projected Population by Age Group, Indonesia 2015-2045 [13]

Based on the 2015 Inter-Census Population Survey (SUPAS), Indonesia's population is estimated to reach 296.6 million and 298 million between 2020-2024, respectively. Indonesia has entered the demographic bonus since after 1980 where the dependency ratio continued to decline and reached its lowest point between 2020-2035.[13] This demographic bonus shows the ability of the productive age population to earn income and contribute to a more positive economic growth. It makes fiscal conditions better due to high tax payments for various things, including health insurance for residents other than those of productive age. This high productive age may also impact the high number of Telehealth users in Indonesia.

\subsection{Public Health Conditions}

In $2020,71 \%$ came from non-communicable diseases, while communicable diseases contributed 20\% to the value of DALYs (Disability Adjusted Life Years). The contribution of Tuberculosis and Diarrhea will decrease even though the value of DALYs does not change much in the projection period. Injuries/injuries will continue to contribute to the DALYs value of $8 \%$ between 2016 and 2024. Cardiovascular disease continues to increase along with the increase in the elderly. Depression and low back and neck pain will 
continue to be 1 percent and 4 percent in 2020-2024 to be the value of DALYs.[13]

The burden of this disease is a threat to the nation because the population of productive age with a large number should contribute to development is threatened due to the high number of non-communicable diseases and unhealthy lifestyles. The state bears the burden of costs through the National Health Insurance (JKN) program managed by the Social Security Administering Body (BPJS) for Health. Most of the JKN funds have to finance non-communicable diseases, so it becomes a heavy burden on state finances. The high number of cases of non-communicable diseases due to an unhealthy lifestyle at a young age is likely to affect the use of Telehealth in Indonesia.

\subsection{Insurance System for Residents}

The Indonesian government strives to achieve universal health coverage (UHC) so that the entire population can receive comprehensive and quality health services without cost constraints. The National Health Insurance/Healthy Indonesia Card (JKN/KIS) program has been in existence since January 1, 2014. The Health Social Security Administration (BPJS) is responsible for this program based on Law Number 40 of 2004 concerning the National Social Security System (SJSN). This program aims to provide public access to health services and provide financial protection. [14] In 2020, most of the participants came from the PBI (APBN) segment by $49.10 \%$. However, the most significant growth in participants from year to year occurred in the non-PBI. Until the end of 2020, the total coverage of JKN/KIS reached 222.4 million people. [15]

Based on Presidential Regulation No. 82/2018 in article 65 on Health Insurance. BPJS Health can use telemedicine as compensation or fulfillment of services in areas with no health facilities. However, more technical and detailed aspects are not yet available. It includes business model reliability, service standards, workflows, patient safety, data protection, quality assurance, e-Health application development, and supervision. [16]

The health insurance program will increase public access to health facilities so that the quality of public health will increase. In the long term, improving the quality of public health will improve the quality of Indonesia's human capital. It will increase the productivity of Indonesian workers and increase output so that people's welfare can increase. In the short term, the existence of the health insurance program as an economic activity affects other economic sectors. Several inputs used by health insurance will produce outputs that economic sectors than will increase national output (production) to improve the welfare of the Indonesian people. The increase in JKN participants will increase investment in the health sector as the construction of health facilities, the production of drugs and medical devices, like telehealth, the food, and beverage industry sector, transportation, financial services, etc.

\subsection{Health Workers and Hospitals}

In the provision of telemedicine services, the resources for providing consultations are doctors, specialists/sub-specialist doctors, other health workers, and other competent personnel in information technology.[17]

The number of doctors in Indonesia is the secondlowest in Southeast Asia, at 0.4 doctors per 1,000 population. It means that Indonesia only has 4 doctors serving its 10,000 people. This number is much lower when compared to Singapore, which has 2 doctors per 1,000 population. Apart from doctors, Indonesia has limited other health workers. The availability of nurses and midwives in Indonesia also has the worst position among other countries. The ratio of nurses is 2.1 per 1,000 population, which means that two people serve 1,000 people in Indonesia.[6] In 2020 the number of medical personnel in Indonesia is 124,449 people, with the highest proportion, namely doctors at 55\%.[15]

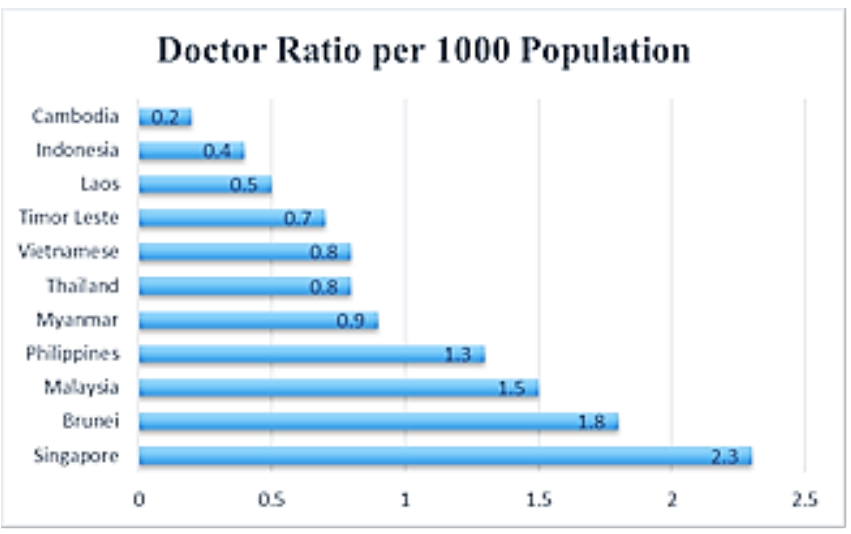

Figure 2 Doctor to Population Ratio [6]

Based on the implementation, hospitals managed by the central government (Kemenkes, TNI/POLRI, K/L, and BUMN), type by the government area (Province, Regency/City), and types of privately owned public hospitals. The ratio of beds to 1,000 inhabitants in Indonesia in 2020 has reached the minimum standard from WHO. However, provinces whose bed ratio does not meet WHO standards, namely West Nusa Tenggara (0.9) and East Nusa Tenggara (0.9). [15]

The number of health workers and health service facilities will affect the health level of a country's population in achieving national development and positive economic growth. The lower the number of health workers and health service facilities impact the poor health status of the community because people cannot access health when experiencing illness, thereby 
reducing work productivity and state income. It is likely to increase Telehealth's business opportunities.

The results of the Inventure Indonesia survey with the Alvara Research Center show that $71 \%$ of consumers trust telemedicine services provided by hospitals more than health startups. Only $29 \%$ of respondents disagree with this statement. It is probably because the telemedicine hospital already has a health service ecosystem and is considered proven security to consumers.[18]

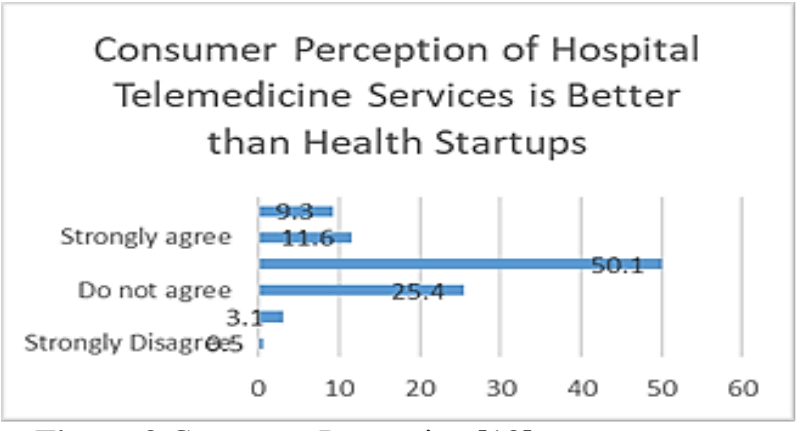

Figure 3 Consumer Perception [18]

Health startups can provide Telemedicine services on their platforms because Telemedicine services are required, such as technical support (technology) and health professionals. However, the elements of health facilities and their permits, health startups have not like hospitals. In addition, the popularity and credibility of hospitals make people prefer hospital telemedicine services to health startups. It is to be a challenge to telehealth from healthcare startups that private companies are not necessarily worse off than government ones.

\subsection{Smartphone Users}

Applications in the health sector or health-tech experienced an increase in visits of up to $600 \%$. There are 32 million new telehealth users who use online health facilities. [19] As many as $75 \%$ of respondents use three types of health applications on their respective cellphones. In the future, this health application is expected to be on target, short term, and provide products according to consumer demand.[20]

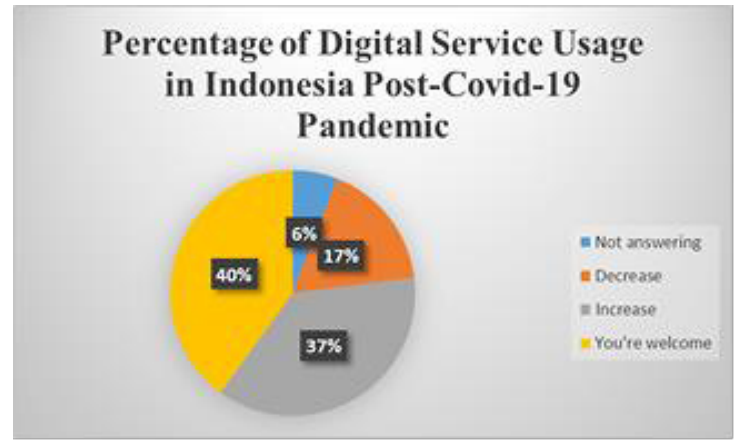

Figure 4 Digital Service Users [20]
As many as $40 \%$ of consumers said they would continue to use digital services after Covid-19, a total of $37 \%$ plan to increase their use. Meanwhile, the rest have reduced their use of digital services as before the pandemic.[21] It shows that people are afraid to come to the hospital for fear of contracting COVID-19, government regulations for large-scale social restrictions, and implementing work from home. It led to high use of telehealth, and people began to rate telehealth from various platforms were the most profitable. The ease of technology is what causes people to continue to use telehealth in the future.

\subsection{Large Online Service Providers or Operating Startups}

In 2017, the Ministry of Health issued a public health service that can be used by the Indonesian people, namely Telemedicine Indonesia (TEMENIN) for teleradiology, tele-EKG, and tele-USG services between health facilities. TEMENIN has 11 health platforms such as: Alodokter, GetWell, Good Doctor, Halodoc, KlikDokter, KlinikGo, Healthy Link, Milvik Dokter, ProSehat, SehatQ, YesDok. [22] DailySocial has just released the results of its research entitled Understanding the Wellness Market in Jakarta 2019. In this report, Halodoc is the most popular application, amounting to $45.3 \%$ of respondents.

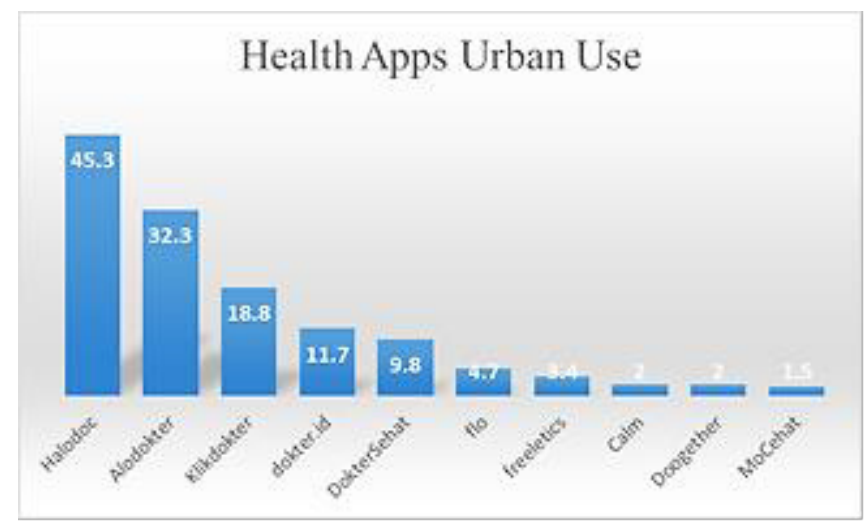

Figure 5 Frequently Used Applications [23]

The application provides health services with a variety of features. In addition to providing health information, Halodoc also provides teleconsultation with doctors and online drug purchases.[23] Great government support for the telehealth business will increase competition in the health sector to produce a quality health service platform.

\subsection{Applicable Cooperation Scheme}

The Ministry of Health has progressively built partnerships with various parties that have developed digital health service platforms. One of them is signing a memorandum of understanding with the Indonesian Telemedicine Association (Atensi) which oversees several start-up companies in the health sector to 
facilitate public access to health services. The Ministry of Health also cooperates with several ministries/agencies including the Ministry of Communication and Informatics, BPJS, Ministry of Home Affairs, to resolve the regulatory and affordability aspects of the telemedicine program. The Ministry of Health is also developing a platform called "Temenin" to build telemedicine access with existing hospitals and health facilities. [24] The cooperation scheme from various stakeholders will improve the quality of telehealth as a form of service to people with community differences, both geographical, social, economic, cultural, racial, gender, etc.

\subsection{Telemedicine Technology-Based Investment Opportunities}

Based on the Press Release of the Ministry of Research, Technology and Higher Education Number: 184/SP/HM/BKKP/IX/2019: Through the Ministry of Research and Technology, the Technology-Based Startup Company (PPBT) scheme and the Technology-Based Start-up Company (CPBT) have fostered 1,307 tenants. Of the 1,307 tenants (period $2014-2019$ ), there are 13 adult tenants with a turnover of more than 1 billion Rupiah per year. Seventeen [17] tenants are growing with a turnover of 500 million to 1 billion Rupiah per year, and 79 tenants with a turnover of 100 million to 500 million Rupiah per year. The Ministry of Research and Technology targets by 2024 to reach 4,900 startups.[25]

In 2022, Frost \& Sullivan Digital Market Overview Indonesia projects that digital health revenues could reach US\$ 726 million with a growth rate of 60 percent per year. One of the digital technology-based health service practices that are developing in Indonesia is telemedicine. The latest implementation has even entered the telehealth level, such as telepharmacy, telelaboratory, virtual medical education, and virtual assistants. [26] With the development of startups in the health sector by the Ministry of Research, Technology, and Higher Education, this telehealth business opportunity is very profitable.

\section{CONCLUSION}

Based on the above review, the telehealth business opportunity in Indonesia is very high. Because Indonesia has a demographic bonus, community support, BPJS insurance regulations related to telemedicine, national e-health strategies, there is a collaboration between several ministries with a Digital Health Service Platform company. However, there are obstacles, namely the low ratio of doctors and health workers to the population.

\section{AUTHORS' CONTRIBUTIONS}

NRA wrote the manuscript, provided data, conducted all statistical analyses, SPS wrote the conclusion, SN wrote method and proofread the manuscript, D wrote the table, ES wrote the literature review, and NP wrote the introduction. All authors reviewed the final manuscript.

\section{ACKNOWLEDGMENTS}

We would like to thank to the Association of KODELN (Collaboration of Lecturers Across Countries) in Indonesia for the support and contribution to this review article so it can be accepted in The International Conference on Social, Economics, Business, and Education (ICSEBE 2021) organized by the University Makassar State (UNM).

\section{REFERENCES}

[1] Koonin LM, Hoots B, Tsang CA, Leroy Z, Farris $\mathrm{K}$, Jolly B, et al. Trends in the Use of Telehealth During the Emergence of the COVID-19 Pandemic - United States, January-March 2020. MMWR Morb Mortal Wkly Rep. 2020;69(43):1595-9.

[2] Calton B, Abedini N, Fratkin M. Telemedicine in the Time of Coronavirus. J Pain Symptom Manage [Internet]. 2020;60(1):e12-4. Available from: https://doi.org/10.1016/j.jpainsymman.2020.03.019

[3] Kichloo A, Albosta M, Dettloff K, Wani F, ElAmir Z, Singh J, et al. Telemedicine, the current COVID-19 pandemic and the future: a narrative review and perspectives moving forward in the USA. Fam Med community Heal. 2020;8(3):1-9.

[4] Mortell TJ, Strobel AT. Changes in the office for civil rights enforcement policy on telehealth remote communications in response to COVID-19. J Pediatr Rehabil Med. 2020;13(3):389-92.

[5] Filippi MK, Callen E, Wade A, Coffman M, Westfall JM, Jabbarpour Y, et al. Covid-19 s financial impact on primary care clinicians and practices. J Am Board Fam Med. 2021;34(3):48997.

[6] Jayani DH. Rasio Dokter Indonesia Terendah Kedua di Asia Tenggara [Internet]. Katadata. 2020. Available from: https://databoks.katadata.co.id/datapublish/2020/04 /02/rasio-dokter-indonesia-terendah-kedua-di-asiatenggara

[7] Sohrabi C, Alsafi Z, O’Neill N, Khan M, Kerwan A, Al-Jabir A, et al. World Health Organization declares global emergency: A review of the 2019 
novel coronavirus (COVID-19). Int $\mathrm{J}$ Surg. 2020;76(February):71-6.

[8] Didier T, Huneeus F, Larrain M, Schmukler SL. Financing firms in hibernation during the COVID19 pandemic. J Financ Stab. 2021;53:100837.

[9] Devita VD. Tren Minat Belanja Online selama Musim Covid-19 di Indonesia. 2020.

[10] Jean-Francois B, Bailey Lash T, Dagher RK, Green Parker MC, Han SB, Lewis Johnson T. The Potential for Health Information Technology Tools to Reduce Racial Disparities in Maternal Morbidity and Mortality. J Women's Heal. 2021;30(2):274-9.

[11] Wosik J, Fudim M, Cameron B, Gellad ZF, Cho A, Phinney $\mathrm{D}$, et al. Telehealth transformation: COVID-19 and the rise of virtual care. J Am Med Informatics Assoc. 2020;27(6):957-62.

[12] Kementrian Kesehatan RI. Peraturan Menteri Kesehatan No 46 Tahun 2017 Tentang Startegi EKesehatan Nasional. 2017.

[13] Setyonaluri D, Aninditya F. Transisi Demografi dan Epidemiologi: Permintaan Pelayanan Kesehatan di Indonesia [Internet]. Direktorat Kesehatan dan Gizi Masyarakat, Kementerian PPN/Bappenas. 2019. 1-43 p. Available from: https://www.bappenas.go.id/files/8515/9339/1872/ FA_Preview_HSR_Book01.pdf

[14] Biro Komunikasi dan Pelayanan Masyarakat KKR. Pemerintah Upayakan Universal Health Coverage Bagi Masyarakat Indonesia [Internet]. Jakarta; 2020. Available from: https://www.kemkes.go.id/article/print/201213000 01/pemerintah-upayakan-universal-healthcoverage-bagi-masyarakat-indonesia.html

[15] RI KK. Profil Kesehatan Indonesia 2020 [Internet]. Kementrian Kesehatan Republik Indonesia. 2021. 139 p. Available from: https://pusdatin.kemkes.go.id/resources/download/ pusdatin/profil-kesehatan-indonesia/Profil-

Kesehatan-Indonesia-Tahun-2020.pdf

[16] Daon001. Layanan Kesehatan dan Kemajuan Teknologi Digital [Internet]. Jakarta; 2019. Available from: https://kominfo.go.id/content/detail/17698/layanankesehatan-dan-kemajuan-teknologidigital/0/sorotan_media

[17] Kesehatan RI K. Peraturan Menteri Kesehatan no 20 Tahun 2019 Tentang Penyelenggaraan Pelayanan Telemedicine antar Fasilitas Pelayanan Kesehatan. Menteri Kesehatan Republik Indonesia Peraturan Menteri Kesehatan Republik Indonesia 2019.
[18] Bayu DJ. Konsumen Lebih Percaya Layanan Telemedicine dari RS [Internet]. Jakarta; 2020. Available from: https://databoks.katadata.co.id/datapublish/2020/11 /17/konsumen-lebih-percaya-layanan-telemedicinedari-rs

[19] Annur CM. Momentum Pandemi, Kominfo Dorong Startup Lokal Saingi Aplikasi Asing [Internet]. Jakarta; 2020. Available from: https://katadata.co.id/ekarina/digital/5f37060be91d f/momentum-pandemi-kominfo-dorong-startuplokal-saingi-aplikasi-asing

[20] Pusparisa Y. Aplikasi Kesehatan Makin Digemari Konsumen [Internet]. Jakarta; 2019. Available from:

https://databoks.katadata.co.id/datapublish/2019/11 /05/aplikasi-kesehatan-makin-digemari-konsumen

[21] Annur CM. Kominfo Minta Talenta Lokal Bikin Aplikasi yang Dibutuhkan saat Corona [Internet]. Jakarta; 2020. Available from: https://katadata.co.id/ameidyonasution/berita/5f178 684207ea/kominfo-minta-talenta-lokal-bikinaplikasi-yang-dibutuhkan-saat-corona

[22] Syafitri I. Perkembangan Telemedicine di Indonesia [Internet]. Jakarta; 2021. Available from: https://www.kompasiana.com/indhirasya/61056378 1525104ae263cc32/perkembangan-telemedicinedi-indonesia

[23] Pusparisa Y. Ini Aplikasi Kesehatan Andalan Kaum Urban [Internet]. Jakarta; 2019. Available from:

https://databoks.katadata.co.id/datapublish/2019/12 /10/ini-aplikasi-kesehatan-andalan-kaum-urban

[24] Yusuf. Perluas Akses Kesehatan, Pemerintah Kembangkan Layanan Telemedis [Internet]. Jakarta; 2020. Available from: https://www.kominfo.go.id/content/detail/28833/pe rluas-akses-kesehatan-pemerintah-kembangkanlayanan-telemedis/0/berita

[25] Suryasumirat RA. Menristekdikti Targetkan Startup Binaan di 2024 Capai 4.900 [Internet]. Jakarta; 2019. Available from: https://www.merdeka.com/peristiwa/menristekdikti -targetkan-startup-binaan-di-2024-capai-4900.html

[26] Hariyanti D. Mengoptimalkan Digital Health di Indonesia [Internet]. Jakarta; 2020. Available from: https://katadata.co.id/saptopradityo/digital/5f60541 c88a24/mengoptimalkan-digital-health-diindonesia 